\title{
ALGORITMA UNTUK MENGKONSTRUKSI SUPER MATRIK SIMETRI FUZZY PERSEGI
}

\author{
Hendra Kartika \\ Program Studi Pendidikan Matematika \\ Universitas Singaperbangsa Karawang \\ Email: hendra.kartika@staff.unsika.ac.id
}

\begin{abstract}
The aim of this paper is to study the super matrix fuzzy using square symmetric properties of the matrix approach. Super fuzzy symmetry square matrix is constructed using the algorithm proposed by the author. The algorithm is derived from the concept of four square fuzzy submatrices. After that, the algorithm is translated into Matlab and repeatedly studied so that it meets super matrix symmetry properties. In this algorithm, Matlab is used to support the construction of super square fuzzy symmetry matrix with a very large order.
\end{abstract}

Keywords : algorithm, fuzzy matrix, square symmetry matrix.

ABSTRAK. Tujuan dari penulisan makalah ini adalah untuk mengkaji super matrik fuzzy dengan pendekatan sifat matrik simetri persegi. Super matrik simetri fuzzy persegi dikonstruksi dengan algoritma yang diusulkan oleh penulis. Algoritma tersebut diperoleh dari konsep empat submatrik fuzzy persegi. Setelah itu, algoritma diterjemahkan ke dalam bahasa matlab serta dikaji secara berulang sehingga memenuhi sifat super matrik simetri. Pada algoritma ini, matlab digunakan untuk mendukung konstruksi super matrik simetri fuzzy persegi dengan orde yang sangat besar.

Kata Kunci : algoritma, matrik fuzzy, matrik simetri persegi.

\section{PENDAHULUAN}

Konsep super matrik fuzzy dan operasinya telah diperkenalkan oleh W. B. V. Kandasamy, F. Smarandache \& K. Amal (2008) pada bukunya yang berjudul “Super Fuzzy Matrices And Super Fuzzy Models For Social Scientists". Namun, dalam buku tersebut hanya disajikan operasi-operasi yang sifatnya mendasar untuk pengembangan pemodelan menggunakan super matrik fuzzy.

Pada makalah ini, penulis mengkaji super matrik fuzzy dengan pendekatan sifat matrik simetri persegi. Super matrik simetri fuzzy persegi dikonstruksi dengan algoritma yang diusulkan oleh penulis. Algoritma tersebut diperoleh dari konsep empat submatrik fuzzy persegi. Setelah itu, algoritma diterjemahkan 
kedalam bahasa Matlab serta dikaji secara berulang sehingga memenuhi sifat super matrik simetri. Pada algoritma ini, Matlab digunakan untuk mendukung konstruksi super matrik simetri fuzzy persegi dengan orde yang sangat besar. Dari penulisan makalah ini, diharapkan adanya kajian-kajian baru serta penerapan super matrik fuzzy pada berbagai bidang seperti pada bidang sains, teknik, sosialekonomi dan pada bidang psikologi.

\section{METODE PENELITIAN}

Metode penelitian yang digunakan dalam penulisan makalah ini adalah studi pustaka (library research)yaitu dengan menelaah beberapa pustaka yang bersumber dari buku, jurnal dan penelitian yang relevan dengan judul makalah yang sedang dikaji. Kajian diawali dari menemukan ide dan menentukan topik makalah, meninjau beberapa pustaka yang sesuai dengan topik makalah, membuat rancangan algoritma, menganalisis algoritma dan menerjemahkan algoritma ke dalam bahasa pemrograman Matlab.

\section{HASIL DAN PEMBAHASAN}

Definisi 1. Menurut Zadeh (Kalaichelvi \& Gnanamalar, 2011:651) Matrik fuzzy adalah suatu matrik dengan nilai unsur-unsur yang terdapat pada interval fuzzy. Pada makalah ini, unit intervalnya adalah $[0,1]$.

Definisi 2. Matrik simetri fuzzy persegi adalah matrik yang mempunyai jumlah baris dan kolom yang sama, memenuhi kaidah simetri dan unsur-unsur pada matrik tersebut berada pada nilai interval $[0,1]$. Misal, $A_{F}=\left[a_{i j}\right]$ matrik fuzzy persegi. Matrik $A_{F}$ dikatakan simetri jika $A_{F}=A_{F}{ }^{T}$ (Joe \& Edal, 2015:881). Dengan kata lain, $A_{F}=\left[a_{i j}\right]$ matrik simetri fuzzy persegi jika setiap unsur $a_{i j}=a_{j i}$ dengan $a_{i j} \in[0,1]$. 
Definisi 3. Super matrik fuzzy adalah matrikr dengan unsur-unsurnya adalah matrik fuzzy itu sendiri (submatrik). Sedangkan unsur-unsur pada submatrik dapat berupa skalar atau matrik (Kandasamy, dkk., 2010:8). Misal, $S_{F}=\left[a_{i j}\right]$ super matrik fuzzy. $S_{F}$ dikatakan super matrik simetri fuzzy persegi jika setiap unsur $a_{i j}=a_{j i}^{t}$ dengan $a_{i j} \in A_{F}$.

Pada makalah ini, super matrik simetri fuzzy persegi yang dikonstruksi berasal dari empat submatrik fuzzy persegi. Secara umum super matrik simetri fuzzy persegi yang dikonstruksi dapat dituliskan sebagai berikut:

$$
S_{F}=\left[\begin{array}{c:c}
a_{1,1} & a_{1,2} \\
\hdashline a_{1,2} & a_{2,2}
\end{array}\right]
$$

a) Langkah-langkah algoritma

1. Membangkitkan matrik random berukuran $2 n \times 2 n$ dengan nilai setiap unsur pada interval $[0,1]$. Variabel $n$ menyatakan ukuran dari submatrik fuzzy persegi. Misal $n=2$, matrik random yang dihasilkan akan berukuran $4 \times 4$ seperti contoh berikut:

$$
S F=\left[\begin{array}{ccc:cc}
0,1999 & 0,7900 & 0,1117 & 0,1897 \\
0,4070 & 0,3185 & 0,1363 & 0,4950 \\
\hdashline 0,7487 & 0,5341 & 0,6787 & 0,1476 \\
0,8256 & 0,0900 & 0,4952 & 0,0550
\end{array}\right]
$$

2. Matrik random yang sudah diperoleh, selanjutnya dikonstruksi sampai memenuhi kaidah matrik simetri.

3. Matrik random yang sudah memenuhi kaidah matrik simetri merupakan super matrik simetri fuzzy persegi dengan pendekatan empat submatrik fuzzy persegi. Contoh matrik di atas, jika sudah memenuhi kaidah matrik simetri akan seperti matrik berikut:

$$
S F=\left[\begin{array}{cc:cc}
0,1999 & 0,7900 & 0,1117 & 0,1897 \\
0,7900 & 0,3185 & 0,1363 & 0,4950 \\
\hdashline 0,1117 & 0,1363 & 0,6787 & 0,1476 \\
0,1897 & 0,4950 & 0,1476 & 0,0550
\end{array}\right]
$$


b) Algoritma tersebut setelah diterjemahkan ke dalam bahasa Matlab, akan seperti pada Gambar 1 berikut:

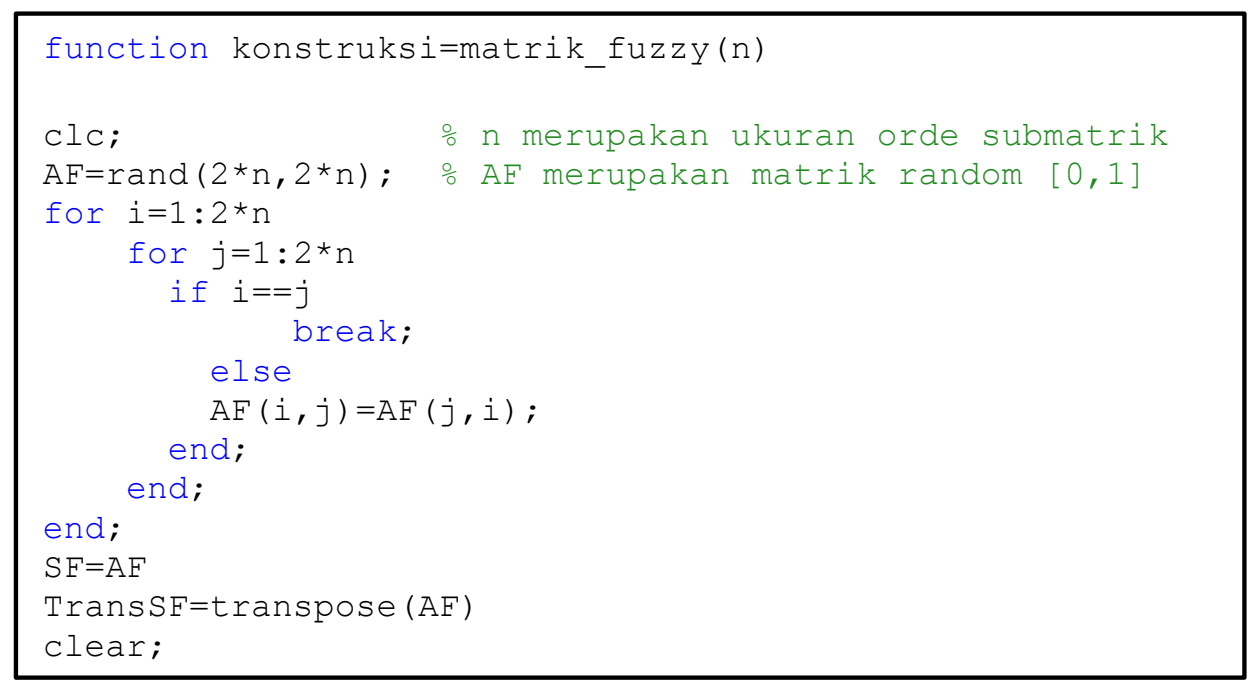

Gambar 1. Algoritma setelah diterjemahkan ke bahasa Matlab

Input dari fungsi Matlab tersebut adalah orde dari submatrik fuzzy persegi. Sedangkan outputnya adalah super matrik simetri fuzzy persegi dengan orde $2 n \times 2 n$.

c) Output dari fungsi Matlab pada Gambar 1, akan seperti pada Gambar 2 dan Gambar 3 berikut:

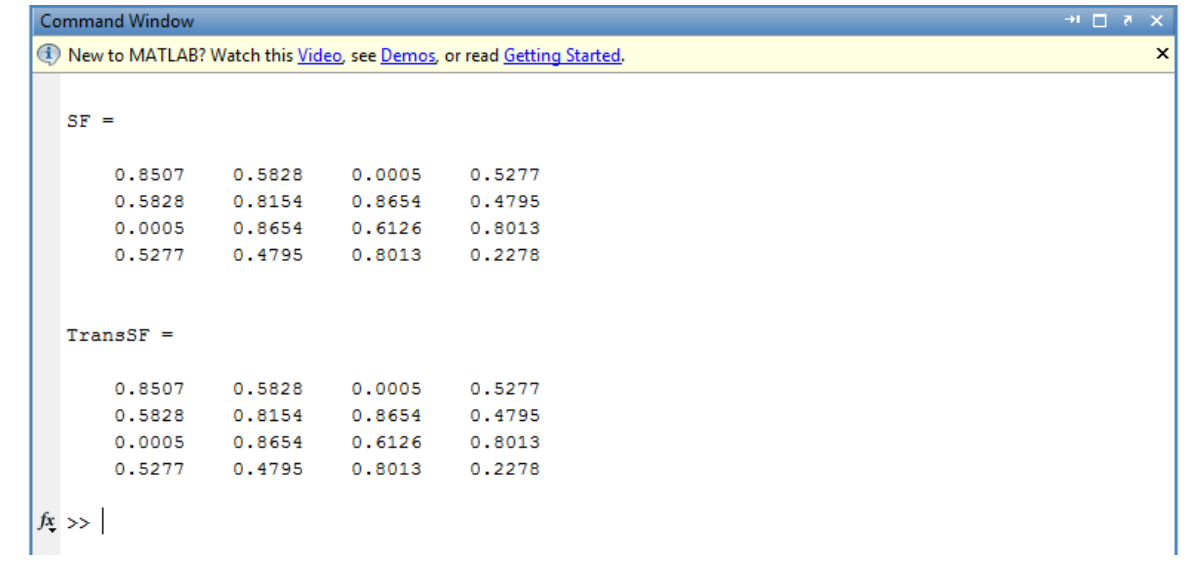

Gambar 2. Output Matlab Super Matrik Simetri Fuzzy Persegi Orde 4×4 


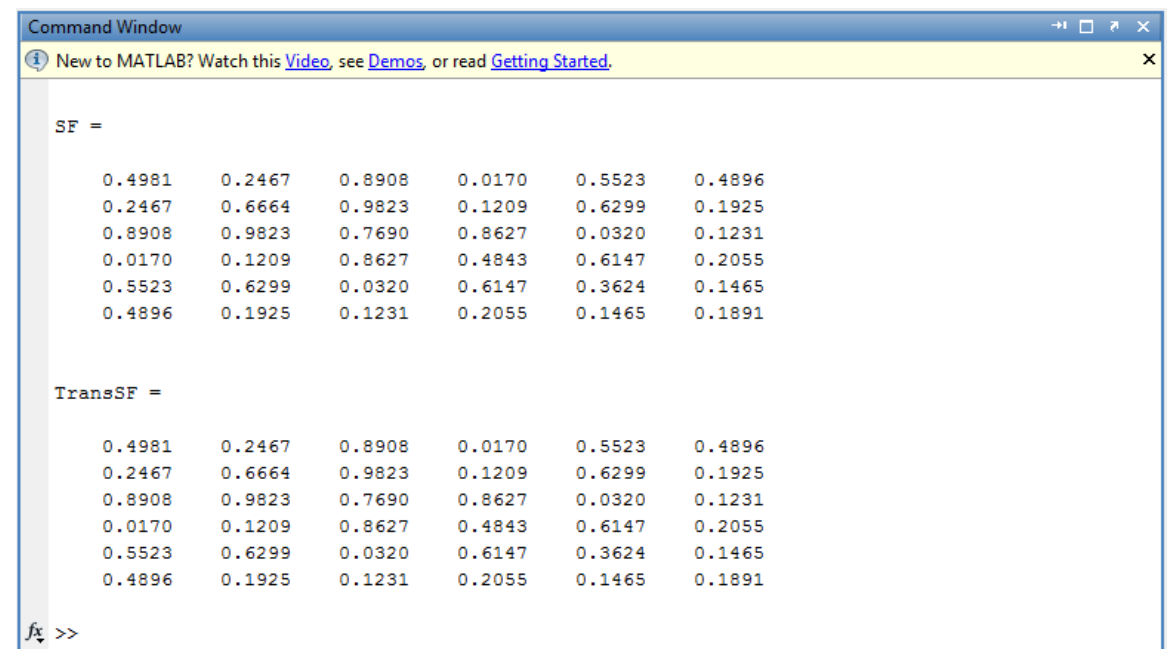

Gambar 3. Output Matlab Super Matrik Simetri Fuzzy Persegi Orde 6×6

Pada Gambar 2 dan Gambar 3, matrik yang dihasilkan adalah matrik SF dan Trans $S F$. Matrik $S F$ merupakan super matrik simetri fuzzy persegi, sedangkan matrik TransSF merupakan matrik transpose dari SF. Jika diperhatikan, $S F=\operatorname{Trans} S F$, artinya $S F=S F^{T}$.

Hal ini menyatakan bahwa output Matlab yang dihasilkan sudah memenuhi kaidah simetri. Sehingga, algoritma yang sudah diterjemahkan ke dalam bahasa Matlab dapat digunakan untuk mengkonstruksi super matrik simetri fuzzy persegi.

\section{KESIMPULAN DAN SARAN}

Dari hasil dan pembahasan di atas, dapat disimpulkan bahwa konstruksi super matrik simetri fuzzy persegi dapat menggunakan pendekatan random sebagai konstruksi awal. Dengan bantuan Matlab, matrik random dikaji secara berulang sampai memenuhi kaidah simetri.

Untuk kajian selanjutnya, diharapkan matrik random tersebut dapat diganti sebagai matrik data. Selain itu, perlu dikaji lebih lanjut tentang super matrik fuzzy pada sifat-sifat matrik yang lain. 


\section{DAFTAR PUSTAKA}

Kalaichelvi, A dan Gnanamalar, S., Application of fuzzy matrices in the analysis of problems encountered by the coffee cultivators in kodai hills, International Journal of Mathematical Sciences and Applications, 1(2) (2010), 651-657.

Kandasamy, W. B. V., Smarandache, F., dan Amal, K., Super Fuzzy Matrices and Super Fuzzy Models for Social Scientists, 2008, https://arxiv.org/ftp/arxiv/papers/0801/0801.2677.pdf., diakses pada 08 Mei 2016.

Kandasamy, W. B. V., Smarandache, F., \& Ilanthenral, K., Super special codes using super matrices, 2010, https://arxiv.org/ftp/arxiv/papers/1006/1006.5790.pdf., diakses pada 09 Mei 2016.

Joe, M.C., dan Edal, M., Eigen Values and Eigen Vectors for Fuzzy Matrix, International Journal of Engineering Research and General Science, 3(1) (2015), 878-890. 